\title{
REVITALISASI KEBIJAKAN PENGEMBANGAN PARIWISATA DALAM MENGHADAPI PENDEMI COVID-19 DI KOTA BIMA
}

\author{
Tauhid ${ }^{1}$, Adi Hidayat Argubi², Ruli Inayah Ramadhoan ${ }^{3}$, Kamaluddin ${ }^{4}$ \\ Administrasi Negara, Sekolah Tinggi Ilmu Sosial dan Ilmu Politik (STISIP) Mbojo, Indonesia ${ }^{1}$ \\ tauhid@stisipbima.ac.id \\ Hubungan Internasional FISIPOL Universitas Muhammadiyah Malang ${ }^{3}$ \\ ruliramadhoan@gmail.com
}

\begin{abstract}
Abstrak
Penelitian ini bertujuan untuk mengetahui bagaimana revitalisasi kebijakan pengembangan pariwisata dalam menghadapi pentebaran pendemi Covid-19 di Kota Bima.Jenis penelitian yang dipakai dalam penelitian ini adalah penelitian deskriptif.Penelitian ini dilakukan di Dinas pariwisata Kota Bima dan daya tarik wisata di Kota Bima.Tahapan pengumpulan data adalah denganobservasi, wawancara berstruktur, dan studi kepustakaan.Sedangkan Tehnik Analisis data yang dipergunakan meliputi Analisis data kualitatif merujuk model interaktifkoleksi data atau pengumpulan data denganmenggunakan analisis data yakni: 1)pengumpulan data lapangan; 2) mereduksidata; dan 3)menarik kesimpulan dan melakukanverifikasi data secara berinteraktif. Hasilpenelitian menunjukkan bahwa revitalisasi destinasi wisata kota bima,mencakup : Destinasi Lawata sebagai wisata bahari dan wisata Kuliner, Destinasi Kolo juga sebagai wisata bahari dan Kuliner, Destinasi Pundunence sebagai wisata pegunungan, Destinasi Ncai Kapenta sebagai wisata olahraga ekstrim, Destinasi Tembakolo sebagai wisata sejarah dan Destinasi sejarah berupa gua peninggalan jepang di Kelurahan Jatibaru Barat dan JatibaruTimur. Hasil penelitian juga menunjukkan bahwa setelah penentuan destinasi obyek wisata, maka Dinas Pariwisata Kota Bima harus melakukan pengelompokan terhadap kegiatan di obyek wisata setelah dilakukan revitalisasi supaya lebih terarah pola pengembangan yang terdiri dari: 1).Pengelompokkan Wisata Air, 2). Kelompok Wisata Hiburan, dan 3). Kelompok Wisata Alam.
\end{abstract}

\section{Kata Kunci: Revitalisasi, Kebijakan, Pengembangan, Pariwisata}

\begin{abstract}
This study aims to find out how to revitalize tourism development policies in the face of the spread of the Covid-19 epidemic in theBima City. Types of research usedin this research is descriptive research. This research conducted in The Bima City tourism office and tourist attractions in the Bima City. The stages of data collection are through observation, structured interviews, and literature study. While the data analysis techniques used include qualitative data analysis referring to the interactive model of data collection or data collection using data analysis namely: 1) field data collection; 2) reduce data; and 3) draw conclusions and interactively verify data. The results showed that the revitalization of the Bima City, including: Lawata Destinations as marine tourism and Culinary tourism, Kolo Destinations as well as marine and culinary tourism, Pundunence Destinations as mountain tourism, Ncai Kapenta Destinations as extreme sports tourism, Tembakolo Destinations as historical tourism and Historical destinations in the form of Japanese heritage cave in West Jatibaru and East Jatibaru. The results of the study also showed that after determining the destination of the tourism objects, the Bima City Tourism Office had to group the activities in the tourism objects after the revitalization so that the development pattern consisted more: 1). Water Tourism Grouping, 2). Entertainment Tourism Group, and 3). Nature Tourism Group.
\end{abstract}

Keyword:Revitalization, Policy, Development, Tourism 


\section{PENDAHULUAN}

Kota Bima sebagai salah satu daerah yang memiliki potensi yang cukup besar untuk menjadi tujuan pariwisata bagi Wisatawan Mancanegara, Wisatawan Nusantara dan lebih-lebih wisatawan lokal dalam hal ini masyarakat Kota Bima maupun Kabupaten Bima yang berkunjung ke tempat-tempat obyek wisata, terutama wisata budaya ada Museum Asi Mbojo, Museum Samparaja, Makam-makam raja Bima dan Sultan Bima di Dana Taraha. Belum lagi wisata alam dan pantai seperti pantai Kolo lebih khusus di Wilayah So Ati yang memiliki keindahan taman laut yang cukup indah dan mempesona di dunia. Disamping itu beragam potensi budaya local seperti kegiatan tradisional upacara adat U'a Pua (yang dilaksanakan setiap Hari Ulang Tahun Kota Bima), Festival Wisata Asakota,Kareku Kandei, Hadra, Gantao, Tarian Wura Bongi Monca, Muna Tembe dansebagainya, menjadikan Kota Bima memiliki keunikan tersendiri dan nilai tambah sebagai primadonawisata di wilayah timur Nusa Tenggara Barat yang tidak akan kita jumpai di daerah lain di ditanahair, apalagi Kota Bima berdekatan dengan kawasan Taman Nasional Komodo yangmenjadi destinasi pariwisata dunia. Oleh karena itu, dalam rangka menjadikan Kota Bima sebagai tujuan wisata, maka tentu diperlukan keberanian dan langkah strategis yang dilakukan Pemerintah Kota Bima dalam memaksimalkan seluruh potensi obyek wisata yang ada di Kota Bima agar tetap eksis dalamdunia kepariwisataan. Kalau selama ini banyak para wisatawan melewati KotaBima untuk tujuan wisata ke Pulau Komodo hanya melewati Kota Bima, makapemerintah daerah harus menangkap peluang pengembangan pariwisata dengan menjadikan Kota Bima sebagai tujuan wisatawan dengan membangun dan menata obyek wisata dengan baik dengan mengedepankan unsur nilai kearifan lokal, menyediakan sarana dan prasarana penunjang seperti hotel dan restaurant yang memadai, dan promosi wisata yang intens yang dilakukan oleh pemerointah Kota Bima maupun dunia usaha terutama mereka yang bergerak di dunia pariwisata, sehingga kedepannya akan dapat meningkatkan Pendapatan Asli Daerah Kota Bima. Berikut disajikan Perkembangan kunjungan wisatawan ke Kota Bima periode tahun 2013-2017, sebagai berikut :

Tabel 1. Arus kunjungan Wisatawan Mancanegara dan Domestik Tahun 2013-2017 di Kota Bima

\begin{tabular}{|l|c|c|c|c|c|}
\hline \multirow{2}{*}{\multicolumn{1}{|c|}{ Wisatawan }} & \multicolumn{5}{c|}{ Jumlah Wisatawan Mancanegara dan Domestik di Kota } \\
& $\mathbf{2 0 1 5}$ & $\mathbf{2 0 1 6}$ & $\mathbf{2 0 1 7}$ & $\mathbf{2 0 1 8}$ & $\mathbf{2 0 1 9}$ \\
\cline { 2 - 6 } & 1157 & 779 & 1152 & 1246 & 1015 \\
\hline $\begin{array}{l}\text { Wisatawan } \\
\text { Mancanegara }\end{array}$ & 18011 & 18724 & 36465 & 38765 & 40231 \\
\hline Wisatawan Domestik & $\mathbf{1 9 1 6 8}$ & $\mathbf{1 9 5 0 3}$ & $\mathbf{3 7 6 1 7}$ & $\mathbf{4 0 0 1 1}$ & $\mathbf{4 1 2 4 6}$ \\
\hline Jumlah & &
\end{tabular}

\section{Sumber Data : BPS Kota Bima, 2020}

Berdasarkan data tersebut menujukkan bahwa peningkatan jumlah kunjungan wisatawan baik dari Mancanegara selama 5 (lima) tahun terus mengalami peningkatan walaupun di penghujung Tahun 2019 mengalami penurunan, namun wisatawan domestic justru mengalami peningkatan yang luar biasa sehingga total kunjungan wisatawan baik mancanegara maupun domestic selama 5 tahun sebanyak 157.545 orang. Terkait dengan hal itu ada 6 (enam) Destinasi wisata Kota Bima yang bias dijadikan destinasi unggulan yaitu : 1). Destinasi Lawata sebagai wisata bahari dan wisata Kuliner, 2) Destinasi Kolo juga sebagai wisata bahari dan Kuliner, 3) Destinasi Pundunence sebagai wisata 
pegunungan, 4). Destinasi Ncai Kapenta sebagai wisata olahraga ekstrim, dan 5)Destinasi Tembakolo sebagai wisata sejarah serta 6) Destinasi sejarah berupa gua peninggalan jepang di kelurahan jatibaru barat dan jatibaru timur.

Namun dalam pengembangan pariwisata di Kota Bima untuk Tahun 2020 sebagaimana di kemukakan oleh Kepala Dinas Pariwisata Kota target kunjungan wisatawan baik mancanegara maupun domestic sebesar 1 juta orang wisatawan. Tidak akan tercapai karena Kota Bima sekarang dihadapkan pada persoalan yang krusual yang mempengaruhi arus kunjungan wisatawan baik mancanegara maupun domestik adalah semakin merebaknya penyebaran virus corona atau dikenal dengan Covid-19 yang sudah mendunia. Dan ini terasa sekali dampaknya dalam semua sector yang menyebabkan kelesuan ekonomi. Semua orang sekarang merasa khawatir dan panic takut jangan sampai terkena Covid-19 ini yang menyebabkan angka penyidap atau pasien lebih khusus Kota Bima berdasarkan rapid test maupun tes swab sebanyak 1 orang. Sementara masih dalam ODP sebanyak 132 orang, dan PDP sebanyak 4 orang(Data tanggal 18 April 2020 yang disampaikan oleh Pemerintah Provinsi Nusa Tenggara Barat).

Berdasarkan kondisi tersebut, maka Peneliti melakukan penelitian terkait dengan: "Revitalisasi Kebijakan Pengembangan Pariwisata Dalam Menghadapi Pendemi Covid-19 di Kota Bima"

\section{METODE PENELITIAN}

Jenis penelitian yang digunakan dalam proses penelitian ini yaitu penelitian deskriptif. Dalam penelitian yang menjadi informan penelitian adalah Sekretaris Daerah Kota Bima, Kepala Dinas Pariwisata Kota Bima, Sekretaris Dinas Pariwisata, Kepala Bidang Pengembangan Destinasi, Pengelola Hotel 1 orang, Pengelola Jasa Usaha Wisata (Tour and Travel) 1 orang dan Pegiat Pariwisata sebanyak 1 orang. Sumber data dalam penelitian ini terdiri dari Data Primer yang diperoleh langsung dari informan penelitian melalui wawancara dan pengamatan dan Data sekunder yang di peroleh dari laporan tertulis dan dokumen yang ada pada Dinas Pariwisata Kota Bima.Sementara itu Tehnik Analisis data yang dipergunakan meliputi Analisisdata kualitatif merujuk model interaktifkoleksi data atau pengumpulan data denganmenggunakan analisis data Miles danHuberman (dalam Sugiyono, 2011) yangmembagi tiga tahapan yakni: 1)pengumpulan data lapangan; 2) mereduksidata dengan cara memilahmilahkan kedalamsatuan konsep tertentu, kategori tertentu atautema tertentu atau meringkaskan datakejadian dan situasi dilokasi penelitiandengan dokumen yang relevan; dan 3)menarik kesimpulan dan melakukanverifikasi data secara berinteraktif, seberapabanyak proses bolak-balik data, tergantungpada kompleksitas permasalahan yanghendak dijawab. (yang dikutip dalam https://media.neliti.com/media/publications/ 146951-ID-implementasi-kebijakanpengembangan-pari.pdf).

\section{RESULT AND DISCUSSION}

Destinasi Wisata Kota BimaYang Bisa Dijadikan Destinasi Unggulan.

Kota Bima memiliki potensi wisata yang luar biasa, baik berupa wisataalam maupun budaya, berada pada banyak titik lokasi destinasi serta tersebar diseluruh wilayah, juga karena kualitas dan daya tariknya yang sangat unik danberagam.Berdasarkan Peraturan Menteri Dalam Negeri nomor 50 tahun 2012 tentangdaya tarik wisata maka objek tujuan masyarakat dapat dibagi dalam 3 kategori yaituobjek wisata alam, wisata buatan dan wisata budaya. Wisata alam adalah objekwisata yang disajikan secara alami tanpa ada sentuhan tangan manusia, wisatabuatan adalah wisata yang telah tersentuh atau terdapat campur tangan manusiasedangkan wisata budaya adalah 
wisata non alam dan wisata yang disajikanbersumber dari kebudayaan daerah (lokal) dapat berupa benda dan tak benda.

Secara umum, destinasi wisata yang akan dipaparkan dalam tulisan ini terdiridari obyek wisata alam dan wisata budaya. Untuk mendapatkan potret destinasiyang sangat banyak dan terpencar tersebut, maka dalam dokumen profil ini akandibahas secara rinci objek wisata di Kota Bima dan dikelompokkanberdasarkan Lokasi Kecamatan sebagai berikut :

\section{Destinasi Lawata Sebagai Wisata} Bahari Dan Wisata Kuliner

Pantai Lawata ibarat sebuah gerbang selamat datang, memberi isyaratbahwa perjalanan akan segera memasuki Kota Bima. Panjang pantai kira-kitasetengah kilometer yang dikelilingi perbukitan yang indah.Di bawahbukitberbatu terdapat sebuah goa peninggalan Jepang.Dahulu tempat ini merupakantempat peristrahatan bagi para bangsawan Bima dan kemudian menjaditempatrekreasi andalan masyarakat yangselalu ramai dikunjungi.

Sarana pariwisata Lawata telah dibangun sejak tahun 2015.Tempat ini duluselalu ramai dikunjungi wisatawan baik wisatawan nusantara maupunmancanegara.Dulu terdapat sarana hotel dilokasi objek ini, namun sekarangkeberadaan sarana pariwisata tersebut sangat memprihatinkan karena sudahditinggalkan oleh pengelolanya.Bangunan yang rusak dan tidak terawat tersebutmemberikan kesan kumuh bagi Pantai Lawata yang sangat indah.Oleh karena itu,pemerintah Kota Bima sejak tahun 2015 telah membangun ulang dan menatakembali Lawata dan menambah atraksi wisata pantai seperti keberadaan BananaBoad, perahu wisata dan berbagai shelter ang disediakan bagi wisatawan.
Fasilitas pariwisata yang ada di Pantai Lawata berupa shelter dan panggunghiburan yang akan menampilkan berbagai macam hiburan dan kesenian rakyat.Fasilitas penyewaan Banana Boad oleh Pemerintah dan fasilitas Kano dan bankaret sudah diusahakan oleh masyarakat sekitar. Di areal sekitar Pantai Lawata, diatas bukit yang menghadap ke arah pantai juga telah dibangun rumah makan dantempat lesehan yang menyajikan berbagai makanan daerah Bima.Pemandangan Pantai Lawata menarik untuk dikembangkan.Pantai yang asridengan airnya yang tenang sangat cocok untuk olah raga air.Panorama keindahanTeluk Bima yang tenang terlihat jelas jika berdiri di atas bukit Pantai Lawata.

2. Destinasi Kolo Juga Sebagai Wisata Bahari Dan Kuliner

Jika memasuki Kota Bima lewat laut akan melewati sebuah celah teluk yangsemakin ke dalam semakin menyempit. Lebarnya hanya sekitar satu kilometer.Dikedua sisinya dipagari bukit dan ada dua buah bukit yang menjorok ke tengahpada masingmasing sisi tersebut seolah menutup teluk. Itulah sebabnya orangBima menyebutnya asa kota atau mulut kota. Di satu bagian bukit sebelah baratterdapat reruntuhan benteng dan meriam kuno peninggalan Belanda.Di bawahbukit terdapat sebuah pantai yang sangat indah.Pantainya berpasir putih, airnyatenang berwarna bening sehingga karang-karang terlihat jelas, dan pohon kelapasepanjang pantai menambah keindahan panorama.Perahu nelayan dan kapalkapal besar yang datang dari berbagai daerah terlihat dengan jelas di sini.Ketenangan air lautnya menjadikan pantai ini sebagai tempat budidaya rumputlaut oleh masyarakat lokal.Perairannya yang tenang sangat bagus untuk berenang,berperahu, 
berselancar, dan menyelam untuk melihat keindahan batu karang danikan hias yang berwarna-warni.

Nama pantai ini adalah Pantai So Ati yang teretak di ujung barat Desa Kolo.Desa ini sangat dinamis.Lebih dari separuh penduduknya adalah pedagangpakaian dan barang elektronik bekas dan Singapura.Dulu kapal Singapura yangmembawa pakaian ke desa ini.Kapal tersebut berlabuh di tengah laut.Nelayandengan perahu motornya mengambil karungkarung bensi barang bekas tersebutdan transaksi dilakukan di laut.Namun sudah banyak pemilik modal di Kolo yangmemiliki armada kapal sendiri untuk mengangkut barang dari Singapura. Di sanamereka biasa berhubungan secara langsung dengan mitra bisnisnya untukmembeli pakaian dan barang elektronik seperti radio, televisi, komputer, dantelepon seluler.

\section{Destinasi Pundunence Sebagai Wisata Pegunungan}

Gunung Pundu Nence atau populer juga dengan singkatan gunung Punce adalah gunung yang terletak di kelurahan Lelamase, kecamatan Rasanae Timur, kota Bima. Gunung dengan ukuran 1.050 mdpl ini sekaligus menjadi puncak tertinggi kota tersebut. Setiap akhir pekan banyak pelajar dan pecinta alam yang mendaki ke puncaknya.Izin pendakian ke Gunung Punce dilakukan di rumah ketua RT setempat.Izin diperlukan lantaran kawasan Gunung Punce ini termasuk dalam cagar alam. Sepanjang rute perjalanan akan banyak dijumpai pemandangan keren termasuk peninggalan sejarah berupa meriam Belanda. Dari puncak gunungnya bakal hadir suguhan sunset yang menawan serta pemandangan dari Gunung Sangiang serta pemandangan alam lainnya yang tak kalah indah.

4. Destinasi Ncai Kapenta Sebagai Wisata Olahraga Ekstrim
Letak Pegunungan Ncai Kapenta sangat strategi untuk pengembangan usaha budidaya Jambu Mete, Nangka, Mangga dan Durian yang memiliki luas $4000 \mathrm{~m}^{2}$. Pegunungan Ncai Kapenta terletak di Kelurahan Jatibaru Timur dan berbatasan dengan Desa Keli Kecamatan Wera Kabupaten Bima. Disela tanaman Jambu Mete sudah dibuatkan jalan pengerasan untuk menghubungkan antara lokasi jambu mete yang satu dengan yang lain. Dan sekarang sudah tembus sampai ke Dusun Ndano Nae Kelurahan Ntobo. Maka tidak salah Pemerintah Kota Bima menetapkan Ncai Kapenta sebagai salah satu Destinasi Wisata untuk kegiatan olahraga ekstrim seperti trabas, motor cross atau sepeda gunung.

5. Destinasi Tembakolo Sebagai Wisata Sejarah

Temba Kolo terletak di Kecamatan Asakota, diperkirakan keberadaanya sudah berumur ratusan tahun. Keadaan batu tersebut dikelilingi oleh batu-batu kecil dan 7 batu besar yang dianggap oleh masyarakat di sekitarnya sebagai Batu Bidadari.Menurut cerita 7 Batu ini sebagai tempat menyimpan selendang 7(tujuh) bidadari yang bilamana mereka mandi dan berenang ditempat ini. Di dalam sumur ini tumbuh sebuah pohon yang disebut pohon awe yang tinggi dan besarnya tidak pernah berubah dari dulu hingga sekarang. Temba Kolo terletak di Kelurahan Kolo. Sumur yang sejak zaman dahulu dikenal oleh masyarakat dengan Temba Kolo ini menyimpan legenda panjang tentang kisah cinta Raja Bima pertama Indra Zamrut dengan puteri kayangan atau yang dikenal dengan Ana Fari Pidu. Salah seorang Ana Fari Itu bernama Puteri Indah yang berhasil dipersunting Raja Indra Zamrut.Dan setelah melahirkan dan menemukan kembali selendangnya, puteri indah 
terbang ke angkasa bersama selendangnya meninggalkan Indra Zamrut dan puteranya.Lalu dengan kekuatan penuh kuda Manggila Indra Zamrut pun tiba di kerajaan Kayangan. Di sana dia menemukan sumur yang persis dengan Temba Kolo di Bumi. Di Kayangan, Indra Zamrut ditangkap pasukan kerajaan dan dihadapkan kepada Raja.Indra Zamrut mengemukakan niat untuk membawa pulang istrinya. Namun Raja Kayangan mengajukan syarat bahwa Indra Zamrut harus melewati tiga tahapan ujian( tahapan ujian itu dilukiskan secara detail dalam kisah Temba Kolo). Akhirnya dengan kesaktian yang dimiliki, Indra Zamrut berhasil melewati ujian tersebut dan membawa pulang Puteri Indah ke Bumi.Maka tidak salah Pemerintah Kota Bima menetapkan Temba Kolo sebagai salah satu Destinasi Wisata budaya.

6. Destinasi Sejarah Berupa Gua Peninggalan Jepang Di Kelurahan Jatibaru Barat Dan Jatibaru Timur

Indonesia pernah dijajah oleh Jepang selama 3,5 tahun. Selama penjajahan masa penjajahan itu, Jepang banyak memanfaatkan gua untuk tempat pertahanan dan tempat menyimpan amunisi.Gua tersebut ada yang memang merupakan gua alami dan ada juga gua buatan yang dibangun oleh orang-orang Indonesia saat mereka menerapkan kerja paksa Romusha. Gua-gua hasil peninggalan Penjajahan Jepang tersebar di Pegunungan Kelurahan Jatibaru Timur dan Kelurahan Jatibaru Barat (dulu Kelurahan Jatibaru) sampai hari ini belum terurus dengan baik sebanyak 12 buah, untuk dijadikan tempat pertahanan, menyimpan amunisi dan stok pangan ketika mereka berperang melawan Tentara Sekutu yang diboncengi Tentata NICA. Perjalanan darat untuk menuju Lokasi Gua-Gua Jepang membutuhkan waktu seharian dan medan nya agak berat dan membutuhkan keahlian khusus. Dan jarak antara gua yang satu dengan yang lain $\pm 5-10 \mathrm{~km}$.

\section{Revitalisasi Kebijakan Pengembangan Pariwisata Dalam Menghadapi Penyebaran Pendemi Covid-19 di Kota Bima}

Dampak dari penyebaran covid19 kian hari semakin mengkhawatirkan dengan meningkatkan pasien covid-19 yang positif. Data Nusa Tenggara Barat khusus Kota Bima berdasarkan rapid test maupun tes swab sebanyak 1 orang. Sementara masih dalam ODP sebanyak 132 orang, dan PDP sebanyak 4 orang (Data tanggal 18 April 2020 yang disampaikan oleh Pemerintah Provinsi Nusa Tenggara Barat). Data Terakhir penyebaran Covid 19 di Nusa Tenggara Barat dapat dijelaskan menurut data berikut ini :

Tabel 2. Kewaspadaan Covid 19 Berdasarkan Kabupaten/Kota di Provinsi NTB (Per 18 April 2020).

\begin{tabular}{|c|c|c|c|c|}
\hline 10. Kabuyptew Kota & Jumbla & ODP & PDP & Konfimasi \\
\hline 1. Kotal.lagram & 534 & 4212 & 83 & 29 \\
\hline 2. Kabo Lombol Bayat & 620 & 587 & 24 & 9 \\
\hline 3. Kabl. Lombox Tengad & 366 & 352 & 13 & 1 \\
\hline 4. Kabo. Lomboox Vara & 238 & 123 & 11 & 3 \\
\hline 5. Kab. Lomboo Iim & 1991 & 1521 & 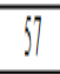 & 13 \\
\hline 6. Kabo. Sumbarra Barat & 133 & 115 & 8 & 0 \\
\hline 1. Kab. Sumbarla & 419 & 394 & UL & 3 \\
\hline 8. Kabb Demong & 99 & 86 & 12 & 1 \\
\hline \begin{tabular}{|l|l|}
9. & Kablobima \\
\end{tabular} & 492 & 482 & 10 & 0 \\
\hline 10. Kota Bimg & 137 & 132 & 3 & 2 \\
\hline \begin{tabular}{l|l}
11. & NDA \\
\end{tabular} & 16 & 11 & 4 & 0 \\
\hline Iotal & $46-5$ & 4336 & 248 & $6 !$ \\
\hline
\end{tabular}

Sumber data : Pemerintah Provisi Nusa Tenggara Barat, April 2020 
Berdasarkan tabel tersebut diatas menunjukkan bahwa total orang baik dalam Orang Dalam Pemantauan (ODP), Pasien Dalam Pemantauan (PDP) serta masih dalam konfirmasi di 10 Kabuppaten/Kota ditambah Warga Negara Asing (WNA) se Nusa Tenggara Barat sebanyak 4.645 orang. Dan status PDP meninggal sebanyak 14 orang.

Oleh karena itu tingginya penyebaran Covid 19 ini di Nusa Tenggara Barat berdampak pada semua sektor lumpuh, termasuk sektor pariwisata yang cukup memberikan kontribusi yang tinggi terhadap penerimaan Pendapatan Asli Nusa Tenggara Barat selama ini ikut merasakan dampak, yang menyebabkan banyaknya usaha jasa perhotelan, agen travic and tour serta usaha jasa pariwisata lainnya mengalami kerugian, sehingga berimplikasi terhadap menurunnya pendapatan mereka,sehingga kebijakan yang diambil managemen perusahaan adalah mengurangi bahkan Pemutusan Hubungan kerja (PHK) terhadap karyawan akibat ketidakberdayaan usaha jasa mereka.

Dengan demikian Kebijakan Pengembangan Pariwisata Kota Bima yang telah dikeluarkan oleh Pemerintah Kota Bima dalam rangka meningkatkan target kunjungan wisatawan Mancanegara maupun Domestik serta pendapatan asli daerah dari kegiatan pariwisata untuk tahun 2020 tidak akan tercapai, karena Kota Bima sekarang masih dalam upaya menuntaskan Virus Corona atau Covid 19 yang sedang melanda Kota Bima. Oleh karenanya Pemerintah Kota Bima melalui Dinas Pariwisata Kota Bima harus melakukan revitalisasi pembaharuan terhadap kebijakan pengembangan pariwisata di Kota Bima di era Penyebaran Covid 19. Revitalisasi Kebijakan pengembangan Pariwisata terhadap pengembangan 6 Destinasi Wisata di Kota Bima, sebagaimana dimaksud diatas, merupakan bagian untuk melestarikan obyek wisata di 6 destinasi wisata, sekaligus pemberdayaan aset Pemerintah
Kota Bima sehingga dapat memberikan kontribusi yang lebih besar terhadap pembangunan dan penyelenggaraan pemerintahan Kota Bima. Dengan program keunggulan yang dimiliki, yaitu Festival Pesona Lawata, meliputi: kegiatan Lomba Perahu, Lomba Renang, Pawai Budaya, Pameran Kuliner, Seminar Budaya, Bakar Ikan Massal dan Makan Ikan Bersama.

Revitalisasi 6 (Enam) Destinasi Wisata sebagai bagian potensi yang besar sebagai kawasan wisata, didukung dengan latar belakang kawasan yang memiliki nilai historis yang kental dengan nilai kearifan lokal yang dimiliki masyarakat Kota Bima. Hal ini sebagaimana dikemukakan oleh Ibu Sunarti, S.Sos, selaku Kepala Dinas Pariwisata Kota Bima dari hasil wawancara dengan peneliti,dengan petikanwawancara sebagai berikut : kebijakan revitalisasi enam destinasi wisata Kota Bima merupakan hasil dari Rapat Koordinasi dengan Tim Percepatan Pembangunan Pariwisata (TP3D) Kota Bima beserta jajarannya perlu ada gebrakan yang cepat dan tepat serta memiliki inovasi dalam merumuskan obyek wisata menjadi kawasan destinasi yang perlu dikembangkan. Walaupun diakui bahwa banyak potensi wisata yang di Kota Bima dibiarkan begitu saja hanya berkembangan dengan sendiri sesuai dengan perlakuan dari masyarakat yang tinggal di kawasan wisata untuk di jadikan sebagai obyek wisata, dengan menarik biaya dari masyarakat dan uangnya masuk kas pribadi dan begitu terus sampai hari ini, sehingga dibiarkan dengan kondisi yang saat itu tidak efektif dan tidak produktif, kurang terawat dan kurang terurus, mempunyai gagasan untuk melaksanakan Rencana Umum Tata Ruang Pembangunan Pariwisata Kota Bima, untuk merevitalisasi menjadi destinasi dan ada dijadikan sebagai taman kota dan ruang terbuka hijau serta taman edukasi.

$$
\text { Kebijakan revitalisasi }
$$

merupakan bagian dari strategi dan program pembangunan kepariwisataan yang dilaksanakan oleh Pemerintah Kota 
Bima. Revitalisasi 6 (Enam) destinasi Kota Bima merupakan perwujudan dukungan sepenuhnya terhadap pelestarian obyek wisata dan budaya sekaligus upaya pemberdayaan potensi KotaBima sebagai Kota tujuan wisata, sehingga dapat memberikan kontribusi yang lebihsignifikan pada penyelenggaraan, pengembangan dan pemberdayaan asetaset Pemerintah Kota Bima.

Dalam menjalankan revitalisasi diperlukan dilakukan beberapa langkah nyata, supaya revitalisasi dapat berhasil dengan baik, sebagaimana dikemukakan oleh (Budihardjo, 1997:222-224), sebagaiberikut:

1. Pertama adalah yang berkaitan dengan peraturan perundangundangan. Peraturan daerah tentang konservasi bangunan dan lingkungan bersejarahsegera disahkan sebagai patokan hukum yang kuat. Dan dengaan adanya perda konservasi, keberadaan dan kelestarian bangunan kuno bersejarah dapat lebih terjamin.

2. Menyusun panduan perencanaan dan perancangan beserta pakar dan konsultan yang kompeten dalam bidang konservasi pada kawasan bersejarah yang akan direvitalisasi. Diharapkan agar keunikan, karakter dan kekhasan bangunan kuno atau kawasan bersejarah dapat terjaga dan ditingkatkan.

3. Kerja sama antara pemerintah dan swasta. Melalui penggalangan dana dan kemitraan tersebut, dapat diupayakan revitalisasi kawasan lama tidak hanyaberorientasi pada kepentingan budaya atau kesejarahan, tetapi kehidupanekonominya juga berkembang.

4. Bertautan dengan upaya pemilikan oleh pemda. Beberapa bangunan kuno yang bermakna dimiliki oleh pemda, atau paling tidak pemda mempunyai saham yang cukup besar pada bangunan tersebut, agar tetap memegang peran yang menentukan masa depan bangunan kuno yang bersangkutan.

5. Menggairahkan iklim investasi di kawasan pusat kota lama. Seandainya sektor swasta yang berminat menanam modal di kawasan bersejarah,misalnya dengan mendirikan hotel, restoran, toko cinderamata, kafetaria, dan lain-lain diberi insentif yang menarik.

6. Keringanan pajak atau tax relief bagi pengusaha atau pemilik bangunan kuno di kawasan bersejarah yang ditetapkan sebagai kawasan konservasi, keringanan pajak itu bisa disertai dengan persyaratan yang mengikat tentangpelestarian dan pemanfaatan bangunan kunonya.

Tahapan pelaksanaan

revitalisasi dalam proses konservasi (Sidhartadan Budihardjo, 1989:15)yaitu:

1. Penjadwalan dan pentahapanrencana fisik

2. Pemilihan usulan-usulan, penggunaanpenggunaan yang sesuai dengan nilainilai lingkungan dan layak dilaksanakan;

3. Menafsirkan kemungkinan kelangsungan perencanaan dalam pelaksanaan terhadap hubungan tingkah laku fisik dan fungsi atau penggunaan serta budayanya

4. Pengelolaan terhadap susunan/tahapan pelaksanaan rencana fisik

5. Pengendalian terhadap lokasi dengan pemeriksaan yang rutin terhadap pengaruh-pengaruh pada fisik dan sosial budayanya

6. Estimasi perubahan/perbaikan oleh pengaruh kegiatan yang akan datang

(Sebagaimana dikutip dalam https://core.ac.uk/download/pdf/12350853. $p d f)$ 


\section{Kondisi Kawasan Destinasi Wisata Sebelum Di Revitalisasi}

Kondisi 6 destinasi wisata sebelum dilakukan pemetaan obyek wisata menjadi kawasan strategi untuk dikembangkan menjadi kawasan keunggulan yang memiliki nilai inovasi dan daya kreasi yang tinggi, sehingga memiliki daya tarik tersendiri bagi para investor maupun wistawan mancanegara dan domestik untuk berkunjung ke destinasi wisata yang ada di Kota Bima, tentu kurang diperhatikan dan terurus dengan baik, sehingga dibiarkan tumbuh secara parsial berdasarkan keinginan masyarakat setempat seperti sepanjang Pantai Kolo, Pantai Ule dan Pantai Amahami. Belum lagi banyak potensi wisata yang belum dijamah sama sekali oleh pemerintah, kalau dikembangkan memiliki keunikakan dan kekhasan tersendiri yang belum tentu dimiliki di tempat lain. Apalagi masyarakat sekarang tempat-tempat yang unik itu pasti ramai dikunjungi terutama wisatawan domestik. Oleh karenna itu Dinas Pariwisata Kota Bima dan Kebijakan Walikota Bima sejalan dengan visi dan Misi Dinas Parieisata Kota Bima, yaitu. "Mewujudkan Kota Bima sebagai kota jasa budaya dan pariwisata yang maju", dengan Misi,yaitu : 1). Melestarikan, menjaga, menggali serta menciptakan potensi wisata dan budaya Bima yang unik, unggul dan bercirikan lokal. 2). Membentuk karakter SDM yang professional dan berkualitas dalam memberikan pelayanan jasa budaya dan pariwisata. Dan 3). Menciptakan jasa objek daya tarik wisata, atraksi budaya dan wisata yang memadai dalam memberikan kepuasan penggunjung.

Sejalan dengan tujuan dan sasaran kebijakan pengembangan pariwisata di Kota Bima, yang mencakup : 1 . Terciptanya potensi budaya dan wisata yang unik, unggul dan bercirikan lokal; 2) Terbentuknya SDM yang berkualitas dalam memberikan pelayanan jasa budaya dan wisata; dan 3) Terciptanya jasa obyek daya tarik wisata serta atraksi budaya dan wisata, maka sasaran yang ingin dicapai meliputi : 1 . Tersedianya potensi budaya dan wisata Bima yang unik, unggul dan bercirikan local; 2 . Tersedianya SDM yang berkualitas dan profesional pada sektor budaya dan wisata; dan 3 . Tersedianya jasa obyek daya tarik wisata serta atraksi wisata budaya yang memadai sehingga mampu memberikan kepuasan terhadap pengunjung. Sehingga Dinas Pariwsata Kota Bima, melakukan revitalisasi obyek wisata agar menjadi daya tarik wisata baik Mancanegara maupun domestik. Pengelompokan Revitalisasi Destinasi Wisata di Kota Bima,meliputi :

\section{Pengelompokkan Wisata Air}

Kelompok wisata air ini sebagai daya tarik tersendiri bagi wisatawan terutama mereka yang hobi bermain ski air,Lomba perahu, Gazebo, setelah revitalisasi kelompok wisata air yang ada sebagai berikut : 1). Kolam Renang di Kawasan Pantai Ule, 2). Penataan Kawasan Pemandian Pantai Lawata dan 3). Penyediaan Fasiltas pendukung seperti Ski,Gazeebo, dan lain-lain.

\section{Kelompok Wisata Hiburan}

Kelompok wisata hiburan yang menckup kesenian tradisional dan modern sering diadakan di destinasi wisata dengan memanfaatkan kondisi dan potensi yangada sekarang, seperti:Hiburan rakyat yang terdiri dari Kesenian dan Tarian Tradisional, Festival Teluk Bima, Lomba Rimpu, Festival LASQI ( Lembaga Seni Qasidah Islam), Upacara Adat Hanta Ua Pua, Pacoa Jara, dan Lomba Kuliner di Pantai Lawata.

\section{Kelompok Wisata Alam}

Trabas atau Motor Cross di Sepanjang Hutan Ncai kapenta dan Pegunungan PundunenceKelurahan Nungga sebagai area olahraga dan wisata alam, Sepeda Gunung, diKawasanDestinasi Wisata Ncai Kapenta dan Penungan kelurahan Lelamase, dan Taman Theurapic, 
masyarakat bisa melewati jalan refleksi sambil menikmati segarnya udara yang ada di sekitar Hutan Ndano Nae, Hutan Jatiwangi dan Menikmati pemandangan menuju Temba Kolo.

Dengan adanya penyelompokan destinasi wisata ini akan mempermudah bagi masyarakat yang akan berkunjung ke obyek wisata. Cuman akhir-akhir ini walaupun sudah dilakukanrevitalisasi pemetaan pengembangan obyek wisata berdasarkan kelompok destinasi wisata yang ada di Kota Bima,namunakhirakhirini Kota Bima khususnya dan Indonesia serta dunia pada umumnya masih dilanda bencana epidemi yaitu Virus Corona Covid 19, yang menghambat pergerakan arus manusia baik itu wisatawan Mancanegara maupun Domestik. Tapi Pemerintah sudah menghimbau melalui Kementerian Kesehatan untuk tetap melakukan Social Distance, Physical Distance, Olah raga yang teratur, makananyang sehat, serta cuci tangan dengan sabun setiap memasuki ruang terbuka dan bila keluar rumah selalu memakai masker. Kalau Prosedur Tetap kesehatan dipatuhi serta dijaga oleh masyarakat,yakinbahwa virus iniakan cepat berakhir. Kemudianyang lebih penting juga adalah dituntut adanya partisipasi dan kesadaran masyarakat dan saling menjaga dan mengingatkan satu sama lain dengan sifat kegotongroyongan yang ada,masyarakat secara serentak menjaga diri dan melakukan lockdaown terhadap setiap orang yang masuk dan keluar di wilayahnya dan melakukan rapid tes dan pengukur suhu tubuh.

Sudah banyak orang yang melakukan tindakan pencegahan dan mitigasi merupakan kunci penerapan di pelayanan kesehatan dan masyarakat. Langkahlangkah pencegahan yang paling efektif di masyarakat meliputi: 1). Melakukan kebersihan tangan menggunakan hand sanitizer jika tangan tidak terlihat kotor atau cuci tangan dengan sabun jika tangan terlihat kotor; 2). menghindari menyentuh mata, hidung dan mulut; 3 ). terapkan etika batuk atau bersin dengan menutup hidung dan mulut dengan lengan atas bagian dalam atau tisu, lalu buanglah tisu ke tempat sampah; 4). Pakailah masker medis jika memiliki gejala pernapasan dan melakukan kebersihan tangan setelah membuang masker; serta 5). Menjaga jarak (minimal $1 \mathrm{~m}$ ) dari orang yang mengalami gejala gangguan pernapasan.(Dikutip dari https://www.jogloabang.com/komunitas/pen cegahan-pengendalian-infeksi-covid-19)

\section{KESIMPULAN}

Walaupun Kota Bima dilanda bencana Virus Corona atau lebih dikenal dengan Covid-19, yang dapat memberikan rasa panik, kekhawatiran dan ketidak tenang masyarakat akibat ganasnya serangan virus ini yang berdampak pada kematian kalau tidak cepat mengantisipasinya, Namun disisi lain Dinas pariwisata Kota Bima tetap melakukan Revitalisasi Destinasi wisata Kota Bima memberikanwarna tersendiri dalam merubaah paradigma bagi pemerintah Kota Bima dan masyarakat dalam menata Obyek Wisata menjadi lebih baik. Keunikan Obyek Wisatadi Kota Bima memberikancirikhas dankarakteristik tersendiri dalam memacu pengembangan destinasi obyek wisata di Kota Bima Bima. Revitalisasi Destinasi obyek wisata di Kota Bima,mencakup : Destinasi Lawata sebagai wisata bahari dan wisata Kuliner, Destinasi Kolo juga sebagai wisata bahari dan Kuliner, Destinasi Pundunence sebagai wisata pegunungan, Destinasi Ncai Kapenta sebagai wisata olahraga ekstrim, Destinasi Tembakolo sebagai wisata sejarah dan Destinasi sejarah berupa gua peninggalan jepang di Kelurahan Jatibaru Barat dan JatibaruTimur. Dan setelah penentuan destinasi obyek wisata, maka Dinas Pariwisata Kota Bima melakukan pengelompokan terhadap kegiatan di obyek wisata setelah dilakukan revitalisasi supaya lebiht erarah pola pengembangan yang terdiri dari : 
1. Pengelompokkan Wisata Air, mencakup:

Kolam Renang di Kawasan Pantai Ule, Penataan Kawasan Pemandian Pantai Lawata dan Penyediaan Fasiltas pendukung seperti Ski,Gazeebo, dll.

2. Kelompok Wisata Hiburan,mencakup : Hiburan rakyat yang terdiri dari Kesenian dan Tarian Tradisional, Festival Teluk Bima, Lomba Rimpu, Festival LASQI ( Lembaga Seni Qasidah Islam), Upacara Adat Hanta Ua Pua, Pacoa Jara dan Lomba Kuliner di Pantai Lawata, serta 3. Kelompok Wisata Alam, terdiri dari : Trabas atau Motor Cross di Sepanjang Hutan Ncai kapenta dan Pegunungan Pundunence Kelurahan Nungga sebagai area olahraga dan wisata alam.Sepeda Gunung, diKawasanDestinasi Wisata Ncai Kapenta dan Penungan kelurahan Lelamaser, Taman Theurapic, masyarakat bisa melewati jalan refleksi sambil menikmati segarnya udara yang ada di sekitar Hutan Ndano Nae, Hutan Jatiwangi dan Menikmati pemandangan menuju Temba Kolo. Dan penelusuran Gua-gua untuk mengetahui benda peninggalan Penjajahan Jepang serta mengetahui tekstur dan struktur dalam gua itu sendiri.

\section{SARAN}

Revitalisasi Kebijakan pengembangan potensi Wisata di Kota Bima adalah sebagai berikut :

1. Untuk mencapai pengembangan potensi yang optimal diperlukan kerja sama yang baik dari berbagai pihak, Pemerintah Kota Bima, masyarakat, swasta ( pebisnis ) maupun Pegiat Pariwisata serta tidak ketinggalan adalah wisatawan sebagai pangsa pasar.

2. Peningkatan destinasi wisata termasuk sarana pendukung dan penunjang fasilitas seperti sarana transportasi, sarana jalan, sarana telekomunikasi, tempat pertunjukan kesenian dan informasi.
3. Ketersediaan sumber daya manusia yang berkulitas dan memadai dalam memperkuat pengembangan pariwisata diberbagai obyek wisata yang ada di Kota Bima.

4. Promosi destinsi wisata yang lebih intensif dan melakukaan hubungan kemitraan dengan biro perjalanan wisata, pemerintah Kota Bima dalam halini Dinas Pariwisata Kota Bima, pengelola wisata, masyarakat dan pegiat wisata lainya, serta.

5. Diupayakan menumbuh kembangkan kesadaran bagi masyarakat sekitar dan wisatawan dalam menjaga kebersihan lingkungan destinasi wisata.

\section{DAFTARPUSTAKA}

Adi Hidayat Argubi, Ruli Inayah Ramadhoan, dan Tauhid, 2019; Analisis Potensi Masyarakat "Uma Lengge" Di Desa Maria Wawo Kabupaten Bima Sebagai Desa Wisata (Tourism Village), Sadar Wisata: Jurnal Pariwisata, Volume 2 Nomor 2 Tahun 2019, (p- ISSN 1858-0112, e-ISSN 15537-37677).

Agustina Pallewa, 2016; Implementasi Kebijakan Pengembangan

Pariwisata Pada Dinas

Kebudayaan Dan Pariwisata Kabupaten Toraja Utara, e Jurnal Katalogis, Volume 4 Nomor 7, Juli 2016 hlm 181-192, ISSN: 23022019.Bappeda Kota Bima, 2018; Rancangan Awal Rencana Pembangunan Jangka Menengah Daerah (RPJMD) Kota Bima 20182023, BAPPEDA Kota Bima

Badan Pusat Statistik, 2019; Kota Bima dalam Angka, Badan Pusat Statistik Kota Bima

Dita Andini, 2011; Skripsi; Revitalisasi Obyek Wisata Taman Balekambang Kota Surakarta, perpustakaan.uns.ac.id, digilib.uns.ac.id, https://core.ac.uk/download/pdf/123 50853.pdf 
Galang Adit Hutsa D,2017; Kajian Implementasi Program Revitalisasi Kawasan Kota Lama Sebagai Kawasan Pariwisata Di Kota Semarang, Journal of Politic and Government Studies, Vol 6, No 04 https://ejournal3.undip.ac.id/index.p hp/jpgs/article/view/17610

Sugiyono, 2011; Metode Penelitian Kuntitatif Kualitatif dan $R \& D$. Alfabeta.

Syarif Ahmad dan Adilansyah, 2016; Laporan Akhir Penelitian Dosen Pemula Pengembangan Pariwisata Kota Bima Sebagai Daerah Transit Wisata Alternatif, Hibah DRPM Kemenristek Dikti Jakarta.

Peraturan Menteri Dalam Negeri nomor 50 tahun 2012 tentang Daya Tarik Wisata https://www.jogloabang.com/komunitas/pen cegahan-pengendalian-infeksicovid-19

https://media.neliti.com/media/publications/ 146951-ID-implementasikebijakan-pengembanganpari.pdf).

https://core.ac.uk/download/pdf/12350853.p df

https://www.jogloabang.com/komunitas/pen cegahan-pengendalian-infeksi-covid-19 